\title{
Aplikasi Asuhan Keperawatan Jiwa Pada Tn. D Dengan Masalah Halusinasi Pendengaran
}

\author{
Nora Lissa Octavia Nainggolan
}

Noranainggolan1210@gmail.com

\section{BAB 1}

\section{PENDAHULUAN}

\subsection{Latar Belakang}

Gangguan jiwa merupakan masalah kesehatan yang serius karena jumlah penyakit yang terus menerus meningkat, termasuk penyakit kronis yang proses penyembuhannya lama. Gangguan jiwa dibagi dua golongan besar yaitu gangguan jiwa ringan dan gangguan jiwa berat. Salah satu bentuk penyakit gangguan jiwa yang berbahaya dan tidak dapat dikontrol yaitu skizofrenia (Hartanto, 2021). Skizofrenia merupakan kondisi psikotik yang berpengaruh terhadap area fungsi individu termasuk berpikir, berkomunikasi, menerima, menafsirkan kenyataan, merasakan dan menunjukkan emosi serta penyakit kronis yag ditandai dengan pikiran kacau, delusi, halusinasi, dan perilaku aneh (Rhoads, 2011 dalam Pardede.2019).

Skizofrenia merupakan gangguan mental berat dan kronis yang menyerang 20 juta orang diseluruh dunia (WHO,2019), sedangkan di Indonesia prevalensi skizofrenia hasil Riskesdes (2018) didapatkan estimasi prevalensi orang yang pernah menderita skizofrenia di Indonesia sebesar 1,8 per 1000 penduduk. Menurut WHO (2021). Prevelensi skizofrenia telah meningkat dari $40 \%$ menjadi 26 juta jiwa. Sedangkan di Indonesia prevelensi skizofrenia meningkat menjadi 20\% penduduk. Prevelensi Sumatera utara meningkat menjadi 7\% penduduk (Riskesdes 2018). 
Halusinasi dapat timbul pada pasien skizofrenia hebefrenik karena didapatkan data pasien yang mengatakan sering mendengar bisikan-bisikan suarayang menyuruhnya untuk marahmarah, pasien sering tertawa sendiri, pasien berbicara ngelantur, serta pasien lebih senang menyendiri dansikap pasien yang pemalu. Kondisi isi pikir dan arus pikir yang terdisorganisasi dan kemampuan kontak dengan kenyataan cenderung burukinidapat menimbulkan halusinasi (Ellina, 2019).

Halusinasi merupakan suatu persepsi panca indera tanpa adanya stimulus eksternal. Dampak yang ditimbulkan dari adaya halusinasi adalah kehilangan kontrol diri, yang mana dalam situasi ini dapat membunuh diri ,membunuh orang lain, bahkan merusak lingkungan. Dalam memperkecil dampak yang ditimbulkan halusinasi dibutuhkan penangan yang tepat. Dengan banyaknya kejadian halusinasi, semakin jelas bahwa peran perawat nntuk membantu pasien agar dapat mengontrol halusinasi (Maulana, 2021).

Merawat pasien skizofrenia dengan masalah halusinasi dibutuhkan pengetahuan, keterampilan dan kesabaran serta dibutuhkan waktu yang lama akibat kronisnya penyakit ini. Anggota keluarga yang bersama pasien skizofrenia menghabiskan lebih banyak waktu di rumah untuk merawat yang sakit dari pada memperhatikan dan mengurusi dirinya. Kemampuan dalam merawat pasien skizoprenia merupakan keterampilan yang harus praktis sehingga membantu keluarga dengan kondisi tertentu dalam pencapaian kehidupan yang lebih mandiri dan menyenangkan (Patricia, 2019).

Berdasarkan survey yang dilakukan oleh penulis di Ruangan rawat Pusuk Buhit Didapatkan jumlah data pasien rawat inap sebayak 22 pasien dengan skizofrenia dengan masalah keperawatan gangguan persepsi sensori halusinasi pendengaran. Subjek dalam pemberian asuhan keperawatan jiwa 
ialah Tn. D. Klien dijadikan sebagai subjek dikarenakan pasien masih sering mendengar suara suara bisikan.

\subsection{Tujuan Penulisan}

\subsubsection{Tujuan Umum}

Untuk memberikan asuhan keperawatan jiwa pada Tn.D dengan gangguan persepsi sensori : Halusinasi

\subsubsection{Tujuan Khusus}

1. Mahasiswa mampu mengetahui defenisi, tanda dan gejala, faktor penyebab, mekanisme koping penatalaksanaan pada pasien dengan Halusinasi.

2. Mahasiswa mampu melakukan pengkajian pada pasien dengan Halusinasi.

3. Mahasiswa mampu menegakkan diagnosa atau masalah keperawatan pada Tn.D dengan Halusinasi.

4. Mahasiswa mampu menetapkan intervensi keperawatan pada diagnosa Halusinasi.

5. Mahasiswa mampu melakukan tindakan keperawatan Halusinasi.

6. Mahasiswa mampu megevaluasi sebagai tolak ukur guna menerapkan asuhan keperawatan dengan Halusinasi. 


\section{BAB 2}

\section{TINJAUAN TEORITIS}

\subsection{Konsep Halusinasi}

\subsubsection{Pengertian}

Halusinasi merupakan salah satu gejala yang sering ditemukan pada klien dengan gangguan jiwa.halusinasi identik dengan skizofrenia. Seluruh klien skizofrenia diantaranya mengalami halusinasi. Halusinasi merupakan gangguan persepsi dimana klien mempersepsikan sesuatu yang banyak terjadi. Suatu penerapan panca indra tanpa ada rangsangan dari luar. Suatu penghayatan yang dialami seperti suatu persepsi melalui panca indra tanpa stimulus eksternal ; persepsi palsu. Berbeda dengan ilusi dimana klien mengalami persepsi pada halusinasi yang terjadi tanpa adanya stimulus yang terjadi. Stimulus internal dipersepsikan sebagai suatu yang nyata ada oleh klien, (Muhith,2015).

Halusinasi merupakan keadaan seseorang mengalami perubahan dalam pola dan jumlah stimulasi yang diprakarsai secara internal atau eksternal disekitar dengan pengurangan, berlebihan, distorsi, atau kelainan berespon terhadap setiap stimulus (Pardede, 2013). Halusinasi pendengaran paling sering terjadi ketika klien mendengar suara - suara, halusinasi ini sudah melebur dan pasien merasa sangat ketakutan, panik dan tidak bisa membedakan antara khayalan dan kenyataan yang dialaminya (Hafizudiin, 2021).

Dari beberapa pengertian yang dikemukakan oleh para ahli mengenai halusinasi di atas, maka penulis dapat mengambil kesimpulan bahwa halusinasi adalah persepsi klien yang salah melalui panca indra terhadap lingkungan tanpa ada stimulus atau rangsangan yang nyata. sedangkan halusinasi pendengaran adalah kondisi di mana pasien mendengar suara, terutama suara-suara orang yang sedang membicarakan apa yang sedang dipikirkannya dan memerintahkan 
untuk melakukan sesuatu. (Muhith, 2015). Berdasarkan beberapa defenisi diatas Halusinasi merupakan gangguan persepsi panca indra, adanya stimulus eksternal yang merasakan sensai palsu namun tidak dapat dirasakan oleh orang lain.

\subsubsection{Etiologi}

Faktor predisposisi klien halusinasi menurut (Oktiviani, 2020) :

1. Faktor Predisposisi

a. Faktor perkembangan Tugas perkembangan klien terganggu misalnya rendahnya kontrol dan kehangatan keluarga menyebabkan klien tidak mampu mandiri sejak kecil, mudah frustasi, hilang percaya diri.

b. Faktor sosiokultural Seseorang yang merasa tidak diterima dilingkungan sejak bayi akan merasa disingkirkan, kesepian, dan tidak percaya pada lingkungan.

c. Biologis Faktor biologis Mempunyai pengaruh terhadap terjadinya gangguan jiwa. Adanya stress yang berlebihan dialami seseorang maka didalam tubuh akan dihasilkan suatu zat yang dapat bersifat halusinogen neurokimia.Akibat stress berkepanjangan menyebabkan teraktivasinya neurotransmitter otak.

d. Psikologis Tipe kepribadian lemah dan tidak bertanggung jawab mudah terjerumus pada penyalahgunaan zat adikitif. Hal ini berpengaruh pada ketidakmampuan klien dalam mengambil keputusan yang tepat demi masa depannya, klien lebih memilih kesenangan sesaat dan lari dari alam nyata menuju alam khayal.

e. Sosial Budaya Meliputi klien mengalami interaksi sosial dalam fase awal dan comforting, klien meganggap bahwa hidup bersosialisasi di alam nyata sangat membahayakan. Klien asyik dengan Halusinasinya, seolah-olah ia merupakan tempat untuk 
memenuhi kebutuhan akan interaksi sosial, kontrol diri dan harga diri yang tidak didapatkan dakam dunia nyata.

\section{Faktor Presipitasi}

Faktor presipitasi merupakan stimulus yang dipersepsikan oleh individu sebagai tantangan, ancaman, atau tuntutan yang memerlukan energi ekstra untuk menghadapinya. Seperti adanya rangsangan dari lingkungan, misalnya partisipasi klien dalam kelompok, terlalu lama tidak diajak komunikasi, objek yang ada di lingkungan dan juga suasana sepi atau terisolasi, sering menjadi pencetus terjadinya halusinasi. Hal tersebut dapat meningkatkan stress dan kecemasan yang merangsang tubuh mengeluarkan zat halusinogenik. Penyebab Halusinasi dapat dilihat dari lima dimensi (Oktiviani, 2020) yaitu :

1. Dimensi fisik: Halusinasi dapat ditimbulkan oleh beberapa kondisi fisik seperti kelelahan yang luar biasa, penggunaaan obat-obatan, demam hingga delirium, intoksikasi alkohol dan kesulitan untuk tidur dalam waktu yang lama.

2. Dimensi Emosional: Perasaan cemas yang berlebihan atas dasar problem yang tidak dapat diatasi merupakan penyebab halusinasi itu terjadi. Isi dari halusinasi dapat berupa perintah memaksa dan menakutkan. Klien tidak sanggup lagi menentang perintah tersebut hingga dengan kondisi tersebut klien berbuat sesuatu terhadap ketakutan tersebut.

3. Dimensi Intelektual: Dalam dimensi intelektual ini menerangkan bahwa individu dengan halusinasi akan memperlihatkan adanya penurunan fungsi ego. Pada awalnya halusinasi merupakan usaha dari ego sendiri untuk melawan impuls yang menekan, namun merupakan suatu hal yang menimbulkan kewaspadaan yang dapat mengambil seluruh perhatian klien dan tidak jarang akan mengontrol semua perilaku klien. 
4. Dimensi Sosial: Klien mengalami interaksi sosial dalam fase awal dan comforting, klien meganggap bahwa hidup bersosialisasi di alam nyata sangat membahayakan. Klien asyik dengan Halusinasinya, seolah-olah ia merupakan tempat untuk memenuhi kebutuhan akan interaksi sosial, kontrol diri dan harga diri yang tidak didapatkan dakam dunia nyata.

5. Dimensi Spiritual: Secara sepiritual klien Halusinasi mulai dengan kehampaan hidup, rutinitas tidak bermakna, hilangnya aktifitas ibadah dan jarang berupaya secara sepiritual untuk menyucikan diri. Saat bangun tidur klien merasa hampa dan tidak jelas tujuan hidupnya. Individu sering memaki takdir tetapi lemah dalam upaya menjemput rezeki, menyalahkan lingkungan dan orang lain yang menyebabkan takdirnya memburuk.

\subsubsection{Tanda Dan Gejala}

Menurut Yuanita (2019). Tanda dan gejala Halusinasi terdiri dari :

a. Menarik diri dari orang lain, dan berusaha untuk menghindar diri dari orang lain

b. Tersenyum sendiri, tertawa sendiri

c. Duduk terpukau (berkhayal)

d. Bicara sendiri

e. Memandang satu arah, menggerakan bibir tanpa suara, penggerakan mata yang cepat, dan respon verbal yang lambat

f. Menyerang, sulit berhubungan dengan orang lain

g. Tiba-tiba marah,curiga, bermusuhan, merusak (diri sendiri, orang lain dan lingkungan) takut

h. Gelisah, ekspresi muka tegang, mudah tersinggung, jengkel,

i. Terjadi peningkatan denyut jantung, pernapasan dan tekanan darah 


\subsubsection{Respon Halusinasi}

Halusinasi merupakan salah satu respon maldaptive individual yang berbeda rentang respon neurobiologi dalam Ini merupakan persepsi maladaptive. Jika klien yang sehat persepsinya akurat, mampu mengidentifisikan dan menginterpretasikan stimulus berdasarkan informasi yang diterima melalui panca indera (pendengaran, pengelihatan, penciuman, pengecapan dan perabaan) klien halusinasi mempersepsikan suatu stimulus panca indera walaupun stimulus tersebut tidak ada.Diantara kedua respon tersebut adalah respon individu yang karena suatu hal mengalami kelainan persensif yaitu salah mempersepsikan stimulus yang diterimanya, yang tersebut sebagai ilusi. Klien mengalami jika interpresentasi yang dilakukan terhadap stimulus panca indera tidak sesuai stimulus yang diterimanya,rentang respon tersebut sebagai berikut(Pardede, Irwan, 2020)

\section{Respon Adaptif}

Respon adaptif adalah respon yang dapat diterima oleh normanorma sosial budaya yang berlaku. Dengan kata lain individu tersebut dalam batas normal jika menghadapi suatu masalah akan dapat memecahkan masalah tersebut, respon adaftif :

a. Pikiran logis adalah pandangan yang mengarah pada kenyataan. Persepsi akurat adalah pandangan yang tepat pada kenyataan.

b. Emosi konsisten dengan pengalaman yaitu perasaan yang timbul dari pengalaman

c. Perilaku sosial adalah sikap dan tingkah laku yang masih dalam batas kewajaran.

d. Hubungan sosial adalah proses suatu interaksi dengan orang lain dan lingkungan. 
2. Respon Maladaptif

Respon maladaptif adalah respon individu dalam menyelesaikan masalah yang menyimpang dari norma-norma sosial budaya dan lingkungan, adapun respon maladaptif meliputi:

a. Kelainan pikiran adalah keyakianan yang secara kokoh dipertahankan walaupun tidak diyakini oleh orang lain dan bertetangan dengan kenyataan sosial.

b. Halusinasi merupakan persepsi sensori yang salah atau persepsi eksternal yang tidak realita atau tidak ada.

c. Kerusakan proses emosi adalah perubahan sesuatu yang timbul dari hati.

d. Perilaku tidak terorganisir merupakan suatu yang tidak teratur.

e. Isolasi sosial adalah kondisi kesendirian yang dialami oleh individu dan diterima sebagai ketentuan oleh orang lain dan sebagai suatu kecelakaan yang negatif mengancam.

\subsubsection{Jenis - Jenis Halusinasi}

Menurut (Pardede, Keliat, 2015) jenis halusinasi antara lain :

1. Halusinasi pendengaran (auditorik) $70 \%$ Karakteristik ditandai dengan mendengar suara, teruatama suara -suara orang, biasanya klien mendengar suara orang yang sedang membicarakan apa yang sedang dipikirkannya dan memerintahkan untuk melakukan sesuatu.

2. Halusinasi penglihatan(visual) $20 \%$ Karakteristik dengan adanya stimulus penglihatan dalam bentuk pancaran cahaya, gambaran geometrik, gambar kartun dan / atau panorama yang luas dan kompleks. Penglihatan bisa menyenangkan atau menakutkan.

3. Halusinasi penghidu (olfactory) Karakteristik ditandai dengan adanya bau busuk, amis dan bau yang menjijikkan seperti: darah, urine atau feses.Kadang - kadang terhidu bau harum.Biasanya berhubungan dengan stroke, tumor, kejang dan dementia. 
4. Halusinasi peraba (tactile) Karakteristik ditandai dengan adanya rasa sakit atau tidak enak tanpa stimulus yang terlihat. Contoh : merasakan sensasi listrik datang dari tanah, benda mati atau orang lain.

5. Halusinasi pengecap (gustatory) Karakteristik ditandai dengan merasakan sesuatu yang busuk, amis dan menjijikkan, merasa mengecap rasa seperti rasa darah, urin atau feses.

6. Halusinasi cenesthetik

7. Karakteristik ditandai dengan merasakan fungsi tubuh seperti darah mengalir melalui vena atau arteri, makanan dicerna atau pembentukan urine.

8. Halusinasi kinesthetic Merasakan pergerakan sementara berdiri tanpa bergerak.

\subsubsection{Fase Fase Halusinasi}

Halusinasi terbagi atas beberapa fase (Oktiviani, 2020):

1. Fase Pertama / Sleep disorder

Pada fase ini Klien merasa banyak masalah, ingin menghindar dari lingkungan, takut diketahui orang lain bahwa dirinya banyak masalah. Masalah makin terasa sulit karna berbagai stressor terakumulasi, misalnya kekasih hamil, terlibat narkoba, dikhianati kekasih, masalah dikampus, drop out, dst. Masalah terasa menekan karena terakumulasi sedangkan support sistem kurang dan persepsi terhadap masalah sangat buruk. Sulit tidur berlangsung trusmenerus sehingga terbiasa menghayal. Klien menganggap lamunanlamunan awal tersebut sebagai pemecah masalah.

2. Fase Kedua / Comforting

Klien mengalami emosi yang berlanjut seperti adanya perasaan cemas, kesepian, perasaan berdosa, ketakutan, dan mencoba memusatkan pemikiran pada timbulnya kecemasan. Ia beranggapan bahwa pengalaman pikiran dan sensorinya dapat dia kontrol bila kecemasannya diatur, dalam tahap ini ada kecenderungan klien merasa nyaman dengan halusinasinya. 
3. Fase Ketiga / Condemning

Pengalaman sensori klien menjadi sering datang dan mengalami bias. Klien mulai merasa tidak mampu lagi mengontrolnya dan mulai berupaya menjaga jarak antara dirinya dengan objek yang dipersepsikan klien mulai menarik diri dari orang lain, dengan intensitas waktu yang lama.

4. Fase Keempat / Controlling Severe Level of Anxiety

Klien mencoba melawan suara-suara atau sensori abnormal yang datang. Klien dapat merasakan kesepian bila halusinasinya berakhir. Dari sinilah dimulai fase gangguan psikotik.

5. Fase ke lima / Conquering Panic Level of Anxiety

Pengalaman sensorinya terganggu. Klien mulai terasa terancam dengan datangnya suara-suara terutama bila klien tidak dapat menuruti ancaman atau perintah yang ia dengar dari halusinasinya. Halusinasi dapat berlangsung selama minimal empat jam atau seharian bila klien tidak mendapatkan komunikasi terapeutik. Terjadi gangguan psikotik berat

\subsubsection{Penatalaksaan Halusinasi}

Penatalaksanaan pasien dengan halusinasi ada beberapa seperti farmakoterapi, terapi kejang listrik, psikoterapi dan rehabilitas yang diantaranya terapi okupasi, terapi sosial, TAK, terapi lingkungan (Prabowo,2014). Terapi okupasi aktivitas menggambar terhadap perubahan halusinasi pada pasien skizofrenia hasil penelitian menunjukan $\mathrm{p}=0,000$. Hasil tersebut menemukan adanya pengaruh terapi okupasi aktivitas menggambar terhadap perubahan halusinasi pada pasien skizofrenia Penelitian.

Aktivitas menanam yang dilakukan bertujuan untuk meminimalisasi interaksi pasien dengan dunianya yang tidak nyata, mengeluarkan pikiran, perasaan, ata emosi yang selama ini mempengaruhi perilaku 
yang tidak disadarinya, memberi motivasi dan memberikan kegembiraan, hiburan, serta mengalihkan perhatian pasien dari halusinasi yang dialami sehingga pikiran pasien tidak terfokus dengan halusinasinya khusus nya pada pasien halusinasi pendengaran (fitri, 2019).

\subsection{Konsep Asuhan Keperawatan}

\subsubsection{Pengkajian}

Pengkajian merupakan pengumpulan data subjektif dan objektif secara, sistematis dengan tujuan membuat penentuantindakan keperawatan bagi individu,kekuarga dan komunitas (Damayanti \& Iskandar,2014). Pada tahap ini ada beberapa yang perlu dieksplorasi baik pada klien yang berkenaan dengan kasus halusinasi yang meliputi :

a. Identitas klien Meliputi nama klien, umur, jenis kelamin, status perkawinan, Agama, tanggal MRS, informan, tanggal pengkajian, nomor rumah klien, dan alamat klien.

b. Keluhan utama Keluhan utama Biasanya berupa bicara sendiri, tertawa sendiri, senyum sendiri, menggerakkan bibir tanpa suara, menarik diri dari orang lain, tidak dapat membedakan yang nyata dan tidak nyata, ekspresi muka tegang mudah tersinggung, jengkel dan marah ketakutan biasa terdapat disorientasi waktu tempat dan orang, tidak dapat mengurus diri dan tidak melakukan kegiatan sehari hari.

c. Faktor predisposisi Faktor predisposisi adalah faktor resiko yang mempengaruhi jenis dan jumlah sumber yang dapat dibangkitkan oleh individu untuk mengatasi stres. Diperoleh baik dari klien maupun keluarganya, mengenai faktor perkembangan sosial kultural, biokimia psikologis dan genetik yaitu faktor resiko yang mempengaruhi jenis dan jumlah sumber yang dapat dibangkitkan oleh individu untuk mengatasi stres. 
1. Faktor perkembangan ; biasanya tugas perkembangan mengalami hambatan dan hubungan interpersonal terganggu maka individu akan mengalami stres dan kecemasan.

2. Faktor sosiokultural ; berbagai faktor di masyarakat dapat menyebabkan seseorang merasa disingkirkan oleh kesepian terhadap lingkungan tempat klien dibesarkan.

3. Faktor biokimia ; adanya stres yang berlebihan dialami seseorang maka di dalam tubuh akan dihasilkan suatu zat yang dapat bersifat halusinogenik neuro kimia.

4. Faktor psikologis; hubungan interpersonal yang tidak harmonis, adanya

peran ganda yang bertentangan dan tidak diterima oleh anak akan

mengakibatkan stres dan kecemasan yang tinggi dan berakhir dengan

gangguan orientasi realitas seperti halusinasi.

5. Faktor genetik; Apa yang berpengaruh dalam skizoprenia. Belum

diketahui, tetapi Hasil studi menunjukkan bahwa faktor keluarga menunjukkan hubungan yang sangat berpengaruh pada penyakit ini.

d. Faktor presipitasi Adanya rangsangan lingkungan yang sering yaitu seperti partisipasi klien dalam kelompok, terlalu lama Diajak komunikasi objek yang ada dilingkungan juga suasana sepi / isolasi adalah sering sebagai pencetus terjadinya halusinasi karena hal tersebut dapat meningkatkan stres dan kecemasan yang merangsang tubuh mengeluarkan zat halusinogenik.

e. Aspek fisikn Hasil pengukuran tanda vital (TD, nadi, suhu, pernapasan, TB, BB) dan keluhan fisik yang dialami oleh klien. Terjadi peningkatan denyut jantung pernapasan dan tekanan darah.

f. Aspek psikososial

Genogram yang menggambarkan tiga generasi. 


\section{g. Konsep Diri}

1. Citra Tubuh

Menolak melihat dan menyentuh bagian tubuh yang berubah/ tidak menerima perubahan tubuh yang terjadi / yang akan terjadi. Menolak penjelasan perubahan tubuh, persepsi negatif tentang tubuh. Preokupasi dengan bagian tubuh yang hilang, mengungkap keputusasaan, mengungkapkan ketakutan.

2. Identitas diri

Ketidak pastian memandang diri, sukar menetapkan keinginan dan tidak mampu mengambil keputusan.

3. Peran

Berubah / berhenti fungsi peran yang disebabkan penyakit, proses menua putus sekolah dan PHK.

4. Harga diri

Perasaan malu terhadap diri sendiri, rasa bersalah terhadap diri sendiri, gangguan hubungan sosial, merendahkan martabat, mencederai diri dan kurang percaya diri.

h. Status mental

Pada pengkajian status mental pasien halusinasi ditemukan data berupa bicara sendiri, senyum sendiri, tertawa sendiri, menggerakkan bibir tanpa suara, pergerakan mata yang cepat, respon verbal yang lambat, menarik diri dari orang lain berusaha untuk menghindari orang lain, tidak dapat membedakan yang nyata dan tidak nyata, terjadi peningkatan denyut jantung pernapasan dan tekanan darah, perhatian dengan lingkungan yang kurang / hanya beberapa detik com berkonsentrasi dengan pengalaman sensori, sulit berhubungan dengan orang lain, ekspresi muka tegang, mudah tersinggung, jengkel dan marah tidak mampu mengikuti perintah dari perawat, tampak tremor dan berkeringat, perilaku panik, agitasi dan kataton curiga dan bermusuhan, bertindak merusak diri orang lain dan lingkungan, ketakutan, tidak dapat mengurus diri, biasa terdapat disorientasi waktu tempat dan orang. 
i. Mekanisme koping

Apabila mendapat masalah, pasien takut / tidak mau menceritakan kepada orang lain (koping menarik diri). Mekanisme koping yang digunakan pasien sebagai usaha mengatasi kecemasan yang merupakan suatu kesepian nyata yang mengancam dirinya. Mekanisme koping yang sering digunakan pada halusinasi adalah

1. Regresi : menjadi malas beraktivitas sehari hari

2. Proyeksi : menjelaskan perubahan suatu persepsi dengan berusaha untuk mengalihkan tanggung jawab kepada orang lain.

3. Menarik diri : sulit mempercayai orang lain dan asyik dengan stimulus internal.

j. Aspek medic

Terapi yang diterima klien bisa berupa terapi farmakologi psikomotor terapi okupasional, TAK dan rehabilitas.

\subsubsection{Diagnosa Keperawatan}

Menurut NANDA 2015 - 2017 yakni gangguan persepsi. Dengan faktor berhubungan dan batasan karakteristik disesuaikan dengan keadaan yang ditemukan pada tiap -tiap partisipan. Topik yang diteliti yakni kemampuan mengontrol halusinasi dengar (Hafizudiin, 2021).

\subsubsection{Intervensi Keperawatan}

Tindakan keperawatan merupakan alat yang dijadikan sebagai panduan oleh seorang perawat jiwa ketika berinteraksi dengan klien dengan gangguan halusinasi. Strategi pelaksanaan adalah penerapan standar asuhan keperawatan yang diterapkan pada pasien yang bertujuan untuk mengurangi masalah keperawatan jiwa yang ditangani. Strategi pelaksanaan pada pasien halusinasi mencakup kegiatan mengenal halusinasi,mengajarkan pasien menghardik, mengajarkan pasien bercakap-cakap dengan orang lain saat halusinasi muncul, serta melakukan aktifitas terjadwal untuk mencegah halusinasi (Susilawati, 2019). 


\subsubsection{Implementasi Keperawatan}

Implementasi disesuaikan dengan rencana tindakan keperawatan. Adapunpelaksanaan tindakan keperawatan jiwa dilakukan berdasarkan Strategi Pelaksanaan (SP) yang sesuai dengan masing-masing masalah utama. Pada saat akan dilaksanakan tindakan keperawatan maka kontrak dengan klien dilaksanakan dengan menjelaskan apa yang akan dikerjakan dan peran serta klien yang diharapkan, dokumentasikan semua tindakan yang telah dilaksanakan serta respon klien (Hafizudiin, 2021).

\subsubsection{Evaluasi Keperawatan}

Evaluasi adalah proses hasil atau sumatif dilakukan dengan membandingkan respon klien pada tujuan umum dan tujuan khusus yang telah ditentukan.halusinasi pendengaran tidak terjadi perilaku kekerasan, klien dapat membina hubungan saling percaya, klien dapat mengenal halusinasinya, klien dapat mengontrol halusinasi dengar dari jangka waktu 4x24 jam didapatkan data subjektif keluarga menyatakan senang karena sudah diajarkan teknik mengontrol halusinasi, keluarga menyatakan pasien mampu melakukan beberapa teknik mengontrol halusinasi. Data objektif pasien tampak berbicara sendiri saat halusinasi itu datang, pasien dapat berbincang - bincang dengan orang lain, pasien mampu melakukan aktivitas terjadwal, dan minum obat secara teratur (Hafizudiin, 2021). 


\section{BAB 3}

\section{TINJAUAN KASUS}

\subsection{Identitas Klien}

Inisial

: Tn.D

Tanggal Pengkajian : 25 Januari 2022

Umur

: 44 Tahun

Agama

: Islam

No Rm

: 03.81 .48

Tanggal MRS

: 14 November 2021

\subsection{Alasan Masuk}

Klien awalnya marah-marah dan merusak barang-barang, mendengar suara suara bisikan dari keluarga mantan istrinya sehingga memukul salah satu anggota keluarganya, klien mengganggu warga sekitar, klien pernah dirawat 1 tahun yang lalu tapi tidak rutin control dan minum obat, klien pernah menikah 2 kali tetapi bercerai karena tidak memberi nafkah. Masalah keperawatan : Gangguan persepsi sensori Halusinasi pendengaran

\subsection{Faktor Predisposisi}

Klien sebelumnya pernah mengalami gangguan jiwa 1 tahun yang lalu tepatnya pada tahun 2019 dan pulan kerumah dalam keadaan tenang. Dirumah klien tidak rutin minum obat, tidak mau kontrol ke RSJ sehingga timbul gejala-gejala sepeti diatas kemudian klien kambuh lagi. Klien awalnya marah-marah dan merusak barang-barang, mendengar suara suara bisikan dari keluarga mantan istrinya sehingga memukul salah satu anggota keluarganya, klien mengganggu warga sekitar, klien pernah dirawat 1 tahun yang lalu tapi tidak rutin control dan minum obat, klien pernah menikah 2 kali tetapi bercerai karena tidak memberi nafkah. Kemudian klien dibawa ke RSJ prof. Dr. Muhammad Ildrem 14 
November 2021. Keluarga klien tidak ada yang pernah mengamali gangguan jiwa.

\subsection{Fisik}

Klien tidak memiliki keluhan fisik, saat dilakukan pemeriksaan tandatanda vital, didapatkan hasil TD : 129/78 mmHg, HR : 95x/i, RR: 20x/i,S: $36,7^{\circ} \mathrm{C}$

Klien memiliki tinggi badan $170 \mathrm{~cm}$ dan berat badan $65 \mathrm{~kg}$.

\subsection{Psikososial}

\subsubsection{Genogram}

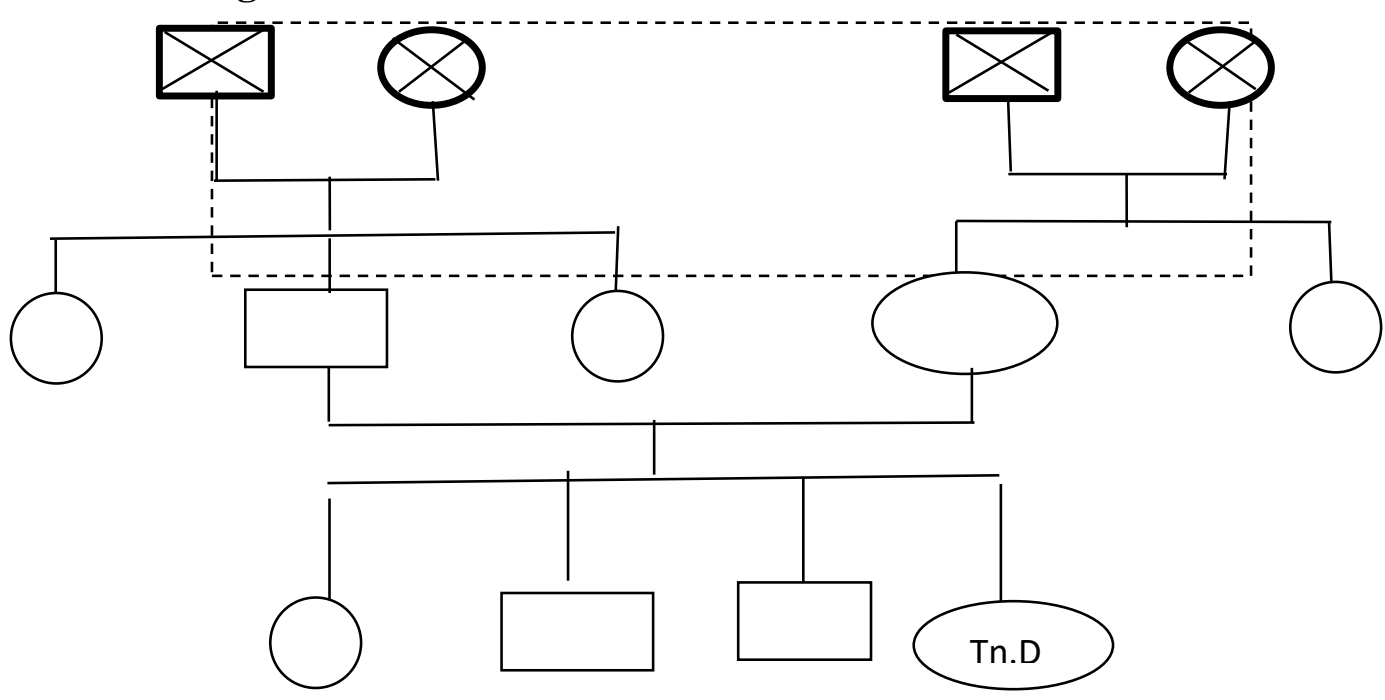

Penjelasan :

klien merupakan anak ke empat dari 4 bersaudara, klien memiliki satu abang dan dua kakak perempuaan yang sudah menikah

keterangan

$$
\begin{array}{ll} 
& \text { : perempuan } \\
\square & : \text { laki-laki } \\
\square & : \text { klien } \\
\pi & : \text { cerai } \\
\square & \text { : garis keturunan } \\
\square & \text { : garis perkawinan } \\
& \text { : tinggal serumah dengan klien }
\end{array}
$$


$\bigotimes:$ meninggal

\subsubsection{Konsep diri}

a. Gambaran diri : Klien menyukai seluruh tubuhnya dan tidak ada yang cacat

b. Identitas : Klien mengetahui nama dan alamatnya klien merupakan anak ke empat dari 4 bersaudara.

c. Peran : Klien berperan sebagai anak

d. Ideal diri $\quad$ : klien merasa malu klien tidak bisa mengendalikan dirinya sendiri dan putus asa

e. Harga diri : Klien mengatakan merasa malu dan gagal karena tidak memberi nafkah kepada istri beserta anaknya dan akhirnya ditinggalkan oleh istrinya.

Masalah keperawatan : Gangguan konsep diri : Harga diri rendah

\subsubsection{Hubungan Sosial}

Klien menggangap bahwa keluarganya adalah orang sangat berarti dalam hidupnya, terutama orang tuanya, klien mengikuti kegiatan seperti perwiritan.

\subsubsection{Spiritual}

a. Nilai dan kenyakinan : Klien beragam islam dan yakin dengan agamnya

b. Kegiatan ibadah : Klien jarang ikut melakukan ibadah selama dirawat

\subsubsection{Status Mental}

1. Penampilan : pasien rapi seperti berpakaian biasa pada umumnya

2. Pembicaraan : klien bicara dengan lambat dan tidak dapat cepat memahami pertanyaan yang diberikan

3. Aktivitas motorik : Klien sering mondar mandir sambil berbicara sendiri, senyum senyum sendiri

4. Suasana perasaan : klien tidak mampu memgapresikan perasaannya pada saat mendengarkan suara-suara 
5. Afek : afek wajah sesuai dengan topik pembicaraan

6. Interaksi selawa wawancara : klien kooperatif saat wawancara

7. Persepsi : klien mengatakan bahwa ia sering mendengar suara-suara yang mengejek dirinya dari keluarga mantan istrinya, klien mendengar suara itu pada saat pagi, siang, dan malam hari namun lebih jelas terdengar di malam hari dank lien merasah gelisah

8. Proses pikir : klien mampu menjawab apa yang ditanya

9. Isi pikir : klien dapat mengotrol isi pikirnya, klien tidak mengalami gangguan isi pikir dan tidak masalah

10. Tingkat kesadaran : klien tidak mengalami gangguan orientasi, klien mengenali waktu orang dan tempat

11. Memori : Klien mampu menceritakan kejadian di masa lalu dan yang baru terjadi.

12. Tingkat konsentrasi berhitung : Klien mampu berkonsentrasi dalam perhitungansederhana tanpa bantuan orang lain.

13. Kemampuan : Klien dapat membedakan hal yang baik dan yang buruk (mampu melakukan penilaian)

14. Daya tilik diri : klien tidak mengingkari penyakit yang diderita klien mengetahui bahwa dia sedang sakit dan dirawat dirumah sakit jiwa Masalah keperawatan : gangguan persepsi sensori : Halusinasi pendengaran

\subsection{Mekanisme Koping}

Klien mengalami mekanisme koping adaptif yaitu klien dapat berbicara baikdengan orang lain.

\subsection{Masalah Psikososial Dan Lingkungan}

Klien mengatakan mau berteman dengan orang lain dan lingkungan sekitar.

\subsection{Pengetahuan Kurang Tentang Gagguan Jiwa}

Klien tidak mengetahui tentang gangguan jiwa yang di alaminya dan obat yang dikonsumsinya. 


\subsection{Aspek Medik}

Diagnosa medis : Skizofrenia paranoid

Terapi medis yang diberikan :

a. Resperidone tablet $2 \mathrm{mg} 2 \times 1$

b. Clozapine $25 \mathrm{mg} 1 \mathrm{x}$

\subsection{Analisa Data}

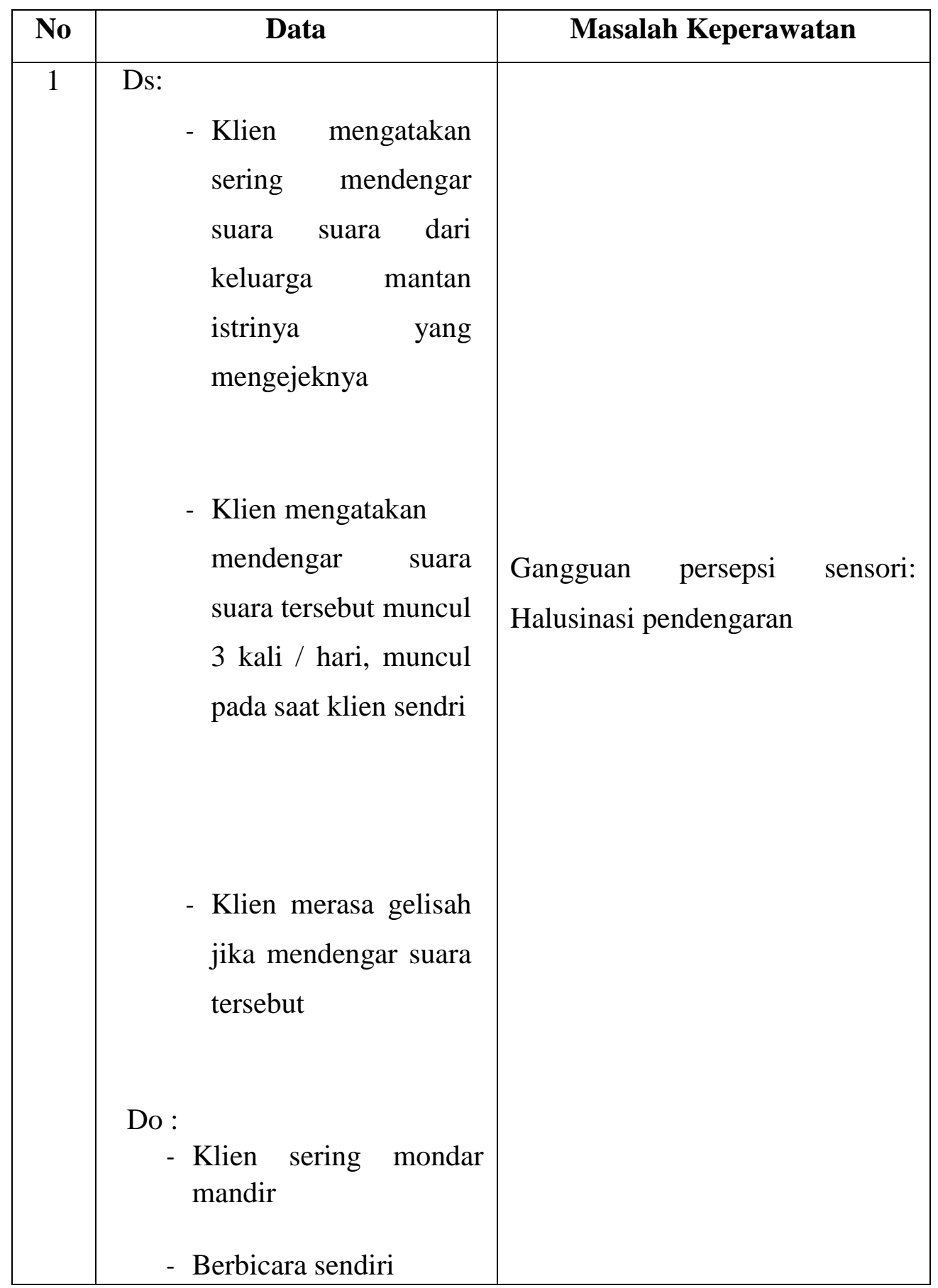




\begin{tabular}{|c|c|c|}
\hline & $\begin{array}{l}\text { - Senyum senyum sendiri } \\
\text { - Berbicara ngawur }\end{array}$ & \\
\hline 2 & 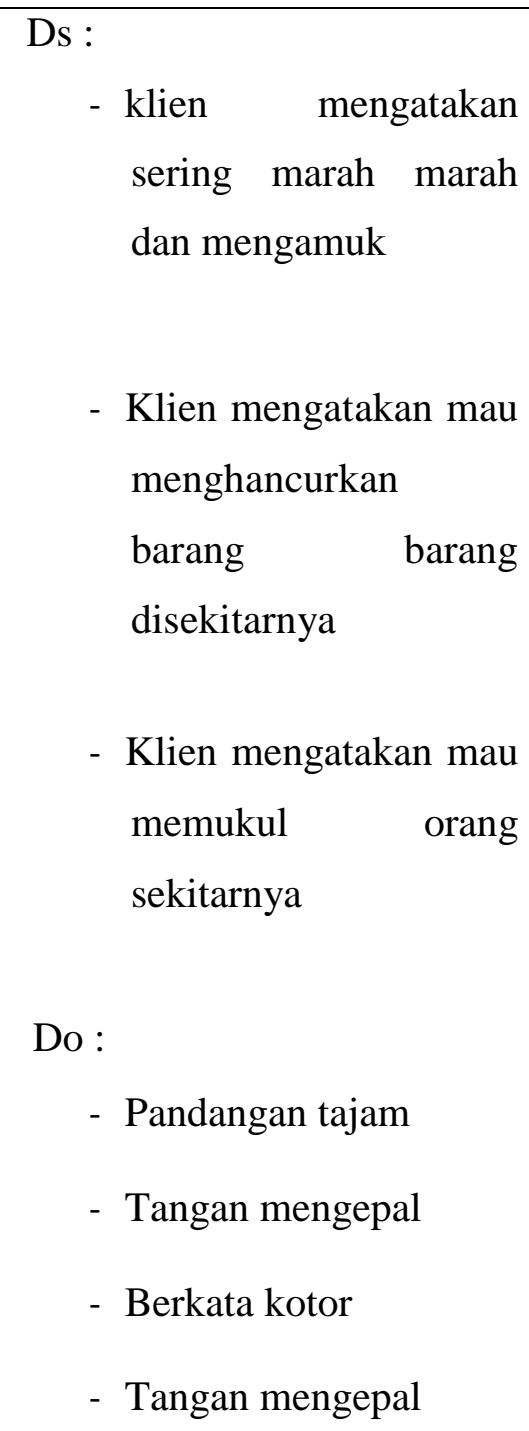 & Risiko perilaku kekerasan \\
\hline 3 & 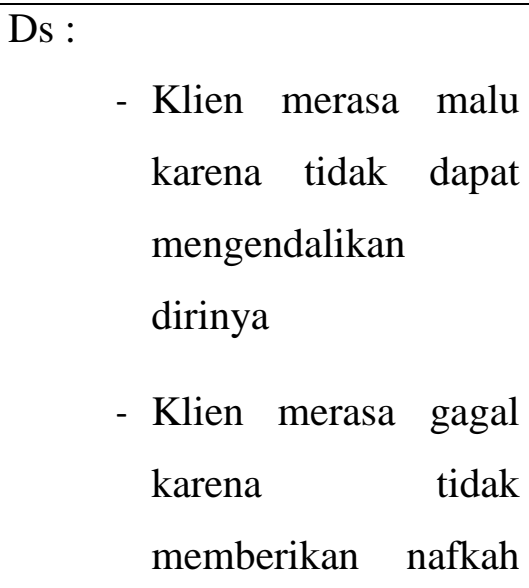 & Harga Diri Rendah \\
\hline
\end{tabular}




$\mid$\begin{tabular}{|c|c|}
\hline & kepada mantan \\
istrinya & \\
- & Klien merasa putus \\
asa karena di & tinggalkan instrinya \\
Do : & \\
- & klien tampak malu \\
- ekspresi wajah & kosong \\
- kontak mata kurang & \\
\hline
\end{tabular}

\subsection{Masalah Keperawatan}

1. Resiko Perilaku kekerasan

2. Gangguan Persepsi Sensori : Halusinasi Pendengaran

3. Gangguan Konsep Diri : Harga Diri Rendah

\subsubsection{Pohon Masalah}

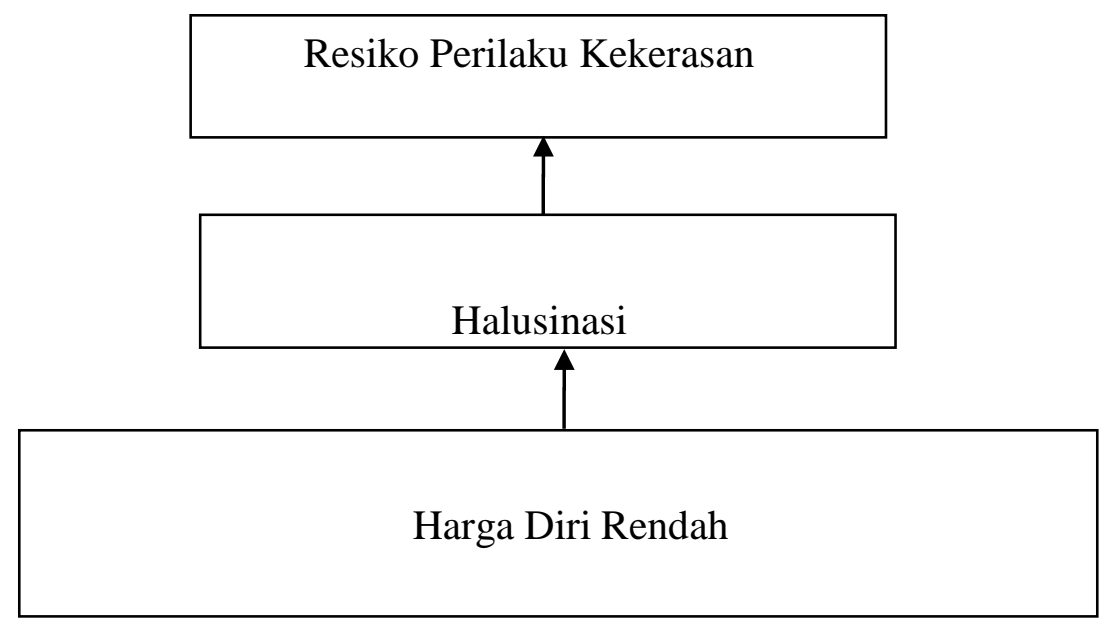

\subsubsection{Prioritas Diagnosa Keperawatan}

Gangguan persepsi Sensorik : Halusinasi pendengaran 
3.1.4 Intervensi Keperawatan

\begin{tabular}{|c|c|c|}
\hline No & Diagnosa & Intervensi \\
\hline 1. & $\begin{array}{l}\text { Gangguan Persepsi Sensori : } \\
\text { Halusinasi Pendengaran }\end{array}$ & $\begin{array}{l}\text { SP 1: } \\
\text { 1. Identifikasi isi, waktu terjadi, situasi } \\
\text { pencetus, dan responterhadap halusinasi } \\
\text { 2. mengontrol halusinasi dengan } \\
\text { cara menghardik } \\
\text { SP 2: } \\
\text { Mengontrol Halusinasi dengan cara minum } \\
\text { obat secara teratur } \\
\text { SP 3: } \\
\text { mengontrol halusinasi dengancara bercakap } \\
\text { - cakap dengan orang lain } \\
\text { SP 4: } \\
\text { mengontrol halusinasi dengan cara } \\
\text { melakukan aktifitas terjadwal }\end{array}$ \\
\hline 2. & Risiko Perilaku Kekerasan & $\begin{array}{l}\text { SP 1: } \\
\text { Mengontrol perilaku kekerasan dengan cara: } \\
\quad \text { - Latihan fisik } 1 \text { : tarik nafas dalam } \\
\text { - Latihan fisik } 2 \text { : pukul kasur bantal } \\
\text { SP 2: } \\
\text { Mengontrol perilaku kekerasan dengan cara } \\
\text { minum obat secara teratur } \\
\text { SP 3: } \\
\text { Komunikasi secara verbal: Asertif/bicara baik } \\
\text { baik } \\
\text { SP 4: } \\
\text { Spiritual }\end{array}$ \\
\hline 3. & $\begin{array}{l}\text { Gangguan Konsep } \\
\text { Harga Diri Rendah }\end{array}$ & $\begin{array}{l}\text { SP 1: } \\
\text { Mengidentifikasi kemampuan dan aspek } \\
\text { positif yang dimiliki pasien } \\
\text { SP 2: }\end{array}$ \\
\hline
\end{tabular}




\begin{tabular}{|l|l|l|}
\hline & $\begin{array}{l}\text { - Menilai kemampuan yang dapat } \\
\text { digunakan } \\
- \text { Menetapkan / memilih kegiatan sesuai } \\
\text { kemampuan } \\
- \text { Melatih kegiatan sesuai kemampuan } \\
\text { yang dipilih 1 } \\
\text { SP 3: } \\
\text { Melatih kegiatan sesuai kemampuan yang } \\
\text { dipilih 2 } \\
\\
\text { SP 4 } \\
\text { Melatih kegiatan sesuai kemampuan yang } \\
\text { dipilih 3 }\end{array}$ \\
\hline
\end{tabular}




\subsection{Implementasi dan Evaluasi}

\begin{tabular}{|c|c|c|}
\hline Waktu & Implementasi & Evaluasi \\
\hline $\begin{array}{l}\text { Selasa, } 25 \\
\text { januari } 2022 \\
10.00\end{array}$ & 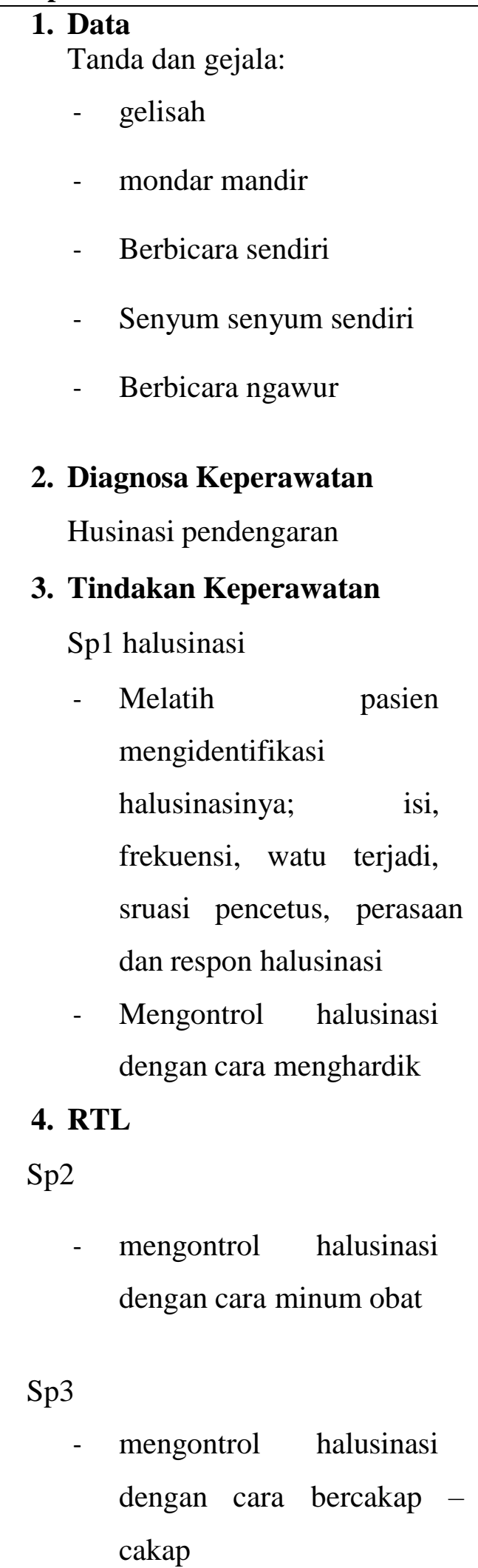 & 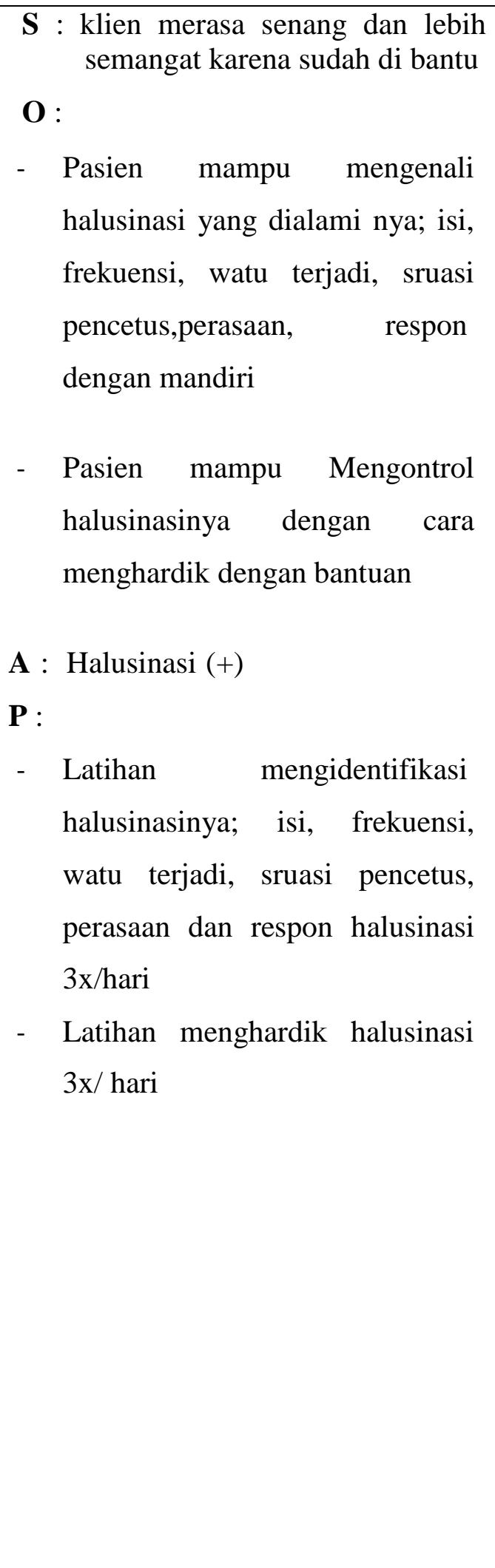 \\
\hline
\end{tabular}




\begin{tabular}{|c|c|c|}
\hline $\begin{array}{l}\text { Rabu, } 26 \\
\text { Januari } 2022\end{array}$ & $\begin{array}{l}\text { 1. Data } \\
\text { Tanda dan Gejala: } \\
\text { - } \text { mendengar suara suara } \\
\text { tersebut muncul } 3 \text { kali / } \\
\text { hari, muncul pada saat } \\
\text { klien sendri } \\
\text { - gelisah } \\
\text { - mondar mandir } \\
\text { - Berbicara sendiri } \\
\text { - Senyum senyum sendiri } \\
\text { 2. Diagnosa keperawatan } \\
\text { Halusinasi pendengaran } \\
\text { 3. Tindakan keperawatan } \\
\text { Sp } 2 \\
\text { Sp3 } \\
\text { - Memberikan informasi tentang } \\
\text { cara penggunaan minum obat } \\
\text { dengan orang lain } \\
\text { - }\end{array}$ & 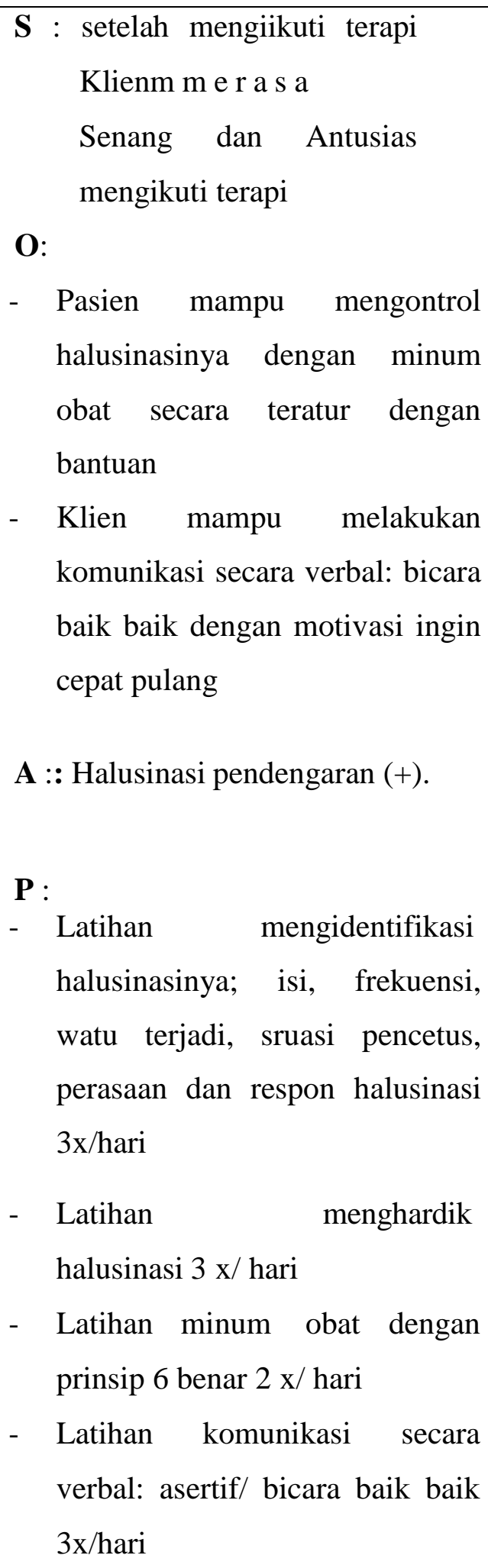 \\
\hline $\begin{array}{l}\text { Kamis, } 27 \\
\text { Januari } 2022 \\
10.00\end{array}$ & $\begin{array}{l}\text { 1. Data } \\
\text { Tanda dan Gejala: } \\
\text { - mendengar suara suara } \\
\text { tersebut muncul } 2 \text { kali / } \\
\text { hari, muncul pada saat }\end{array}$ & $\begin{aligned} \mathbf{S}: & \text { Klien mengatakan dia } \\
& \text { merasa senang bisa } \\
& \text { bercakap cakap dengan } \\
& \text { orang lain }\end{aligned}$ \\
\hline
\end{tabular}




\begin{tabular}{|c|c|c|}
\hline & $\begin{array}{l}\text { klien sendri } \\
\text { - } \text { mondar mandir } \\
\text { - } \quad \text { Berbicara sendiri } \\
\text { - } \quad \text { Senyum senyum sendiri } \\
\text { - } \quad \text { Tertawa sendiri } \\
\text { 2. Diagnosa keperawatan } \\
\text { Halusinasi pendengaran } \\
\text { 3. Tindakan keperawatan } \\
\text { Sp } 4 \text { kemampuan } \\
\text { Mengevaluasi } \\
\text { menghardik Halusinasi } \\
\text { Melatih pasien } \\
\text { melakukan kegiatan spiritual } \\
\text { dengan cara berdoa } \\
\text { Halusinasi } \\
\text { evaluasi sp 1-4 Halusinasi }\end{array}$ & $\begin{array}{l}\text { O: } \\
\text { Klien mampu bercakap cakap } \\
\text { dengan orang lain secara } \\
\text { mandiri } \\
\text { A :: Halusinasi pendengaran (+). } \\
\text { P : Intervensi dilanjutkan } \\
\text { - Latihan } \\
\text { halusinasi } 3 \text { x/ hari } \\
\text { - Latihan minum obat dengan } \\
\text { prinsip } 6 \text { benar } 2 \text { x/ hari } \\
\text { - Latihan bercakap cakap dengan } \\
\text { orang lain } 3 x / h a r i \\
\text { - Latihan kegiatan spiritual }\end{array}$ \\
\hline $\begin{array}{l}\text { Jumat, } \\
\text { januari } 2022 \\
10.00\end{array}$ & $\begin{array}{l}\text { 1. Data } \\
\text { - marah marah dan } \\
\text { mengamuk } \\
\text { - } \text { menghancurkan barang } \\
\text { barang } \\
\text { - memukul orang sekitar } \\
\text { - Pandangan tajam } \\
\text { - Tangan mengepal } \\
\text { - Berkata kotor }\end{array}$ & $\begin{array}{l}\text { S: } \text { klien merasa senang dan } \\
\text { bersemangat melakukan terapi } \\
\text { O: } \\
\text { - Klien mampu melakukan } \\
\text { latihan fisik tarik nafas dalam } \\
\text { dengan mandiri } \\
\text { - Klien mampu pukul kasur } \\
\text { bantal dengan mandiri } \\
\text { A: Resiko Perilaku Kekerasan }(+)\end{array}$ \\
\hline
\end{tabular}




\begin{tabular}{|c|c|c|}
\hline & $\begin{array}{l}2 \text { Diagnosa keperawatan } \\
\text { Resiko Perilaku } \\
\text { Kekerasan } \\
\text { 3 Tindakan keperawatan } \\
\text { Sp 1: } \\
\text { Mengontrol perilaku kekerasan } \\
\text { dengan cara: } \\
\text { - Latihan fisik 1 : tarik nafas } \\
\quad \text { dalam } \\
\text { - Latihan fisik } 2 \text { : pukul kasur } \\
\quad \text { bantal } \\
\text { RTL } \\
\text { Sp } 2 \\
\text { Mengontrol perilaku kekerasan } \\
\text { dengan cara minum obat secara } \\
\text { teratur } \\
\text { Sp } 3 \\
\text { Komunikasi } \\
\text { Asertif/bicara baik baik } \\
\text { Sp } 4 \\
\text { Spiritual }\end{array}$ & 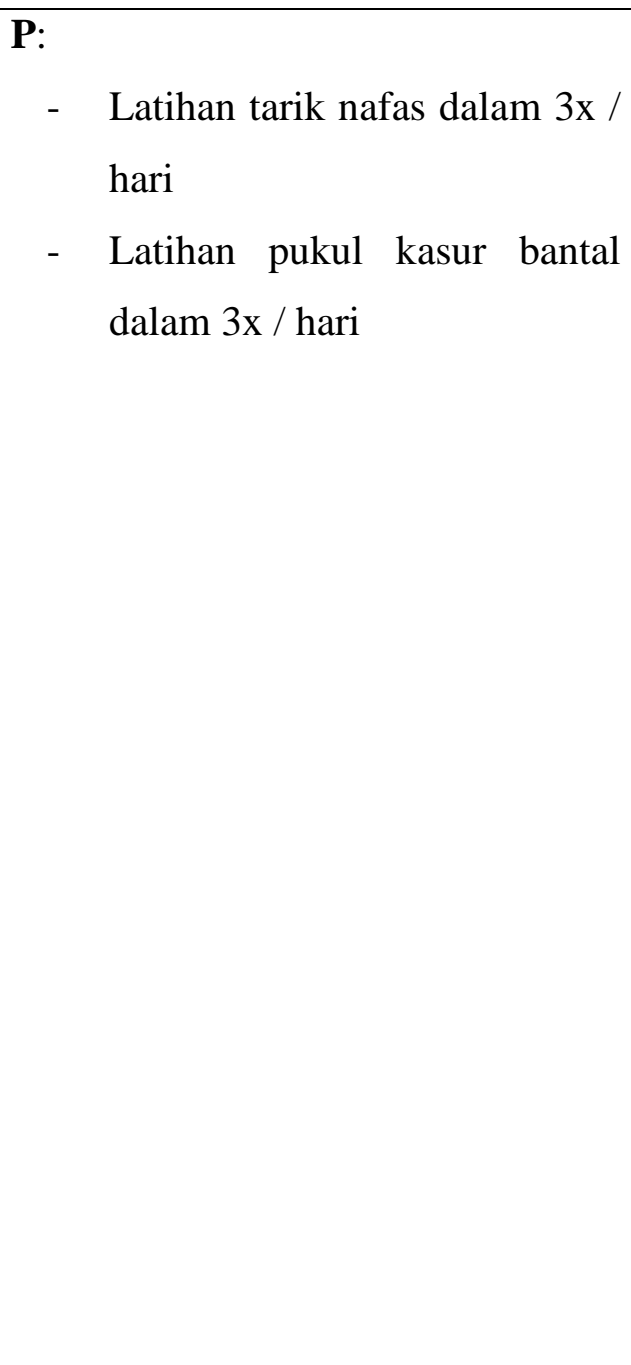 \\
\hline $\begin{array}{l}\text { Sabtu } 29 \text { januari } \\
2022 \\
10.00\end{array}$ & $\begin{array}{l}\text { 1. Data } \\
\text { Tanda dan Gejala: } \\
\text { - mudah marah } \\
\text { - memukul orang sekitar } \\
\text { - Pandangan tajam } \\
\text { - Tangan mengepal } \\
\text { - Berkata kotor } \\
\text { 2. Diagnosa keperawatan } \\
\text { Resiko Perilaku } \\
\text { Kekerasan } \\
\text { 3. Tindakan keperawatan } \\
\text { Sp } 2\end{array}$ & $\begin{array}{l}\text { S: klien merasa senang dan antusias } \\
\text { melakukan terapi } \\
\text { O: } \\
\text { - Pasien mampu mengontrol } \\
\quad \text { perilaku kekerasan dengan } \\
\quad \text { cara minum obat secara } \\
\text { teratur dengan bantuan } \\
\text { A: Resiko Perilaku Kekerasan }(+) \\
\text { P: } \\
\text { - Latihan tarik nafas dalam } 3 x \text { / } \\
\text { hari }\end{array}$ \\
\hline
\end{tabular}




\begin{tabular}{|c|c|c|}
\hline & $\begin{array}{l}\text { - Memberikan informasi tentang } \\
\text { cara penggunaan minum obat } \\
\text { 4.RTL } \\
\text { Sp } 3 \\
\text { Komunikasi secara verbal: } \\
\text { Asertif/bicara baik baik } \\
\text { Sp } 4 \\
\text { Spiritual }\end{array}$ & $\begin{array}{l}\text { - Latihan pukul kasur bantal } \\
\text { dalam } 3 \mathrm{x} / \text { hari } \\
\text { - Latihan minum obat dengan } \\
\text { prinsip } 6 \text { benar } 2 \mathrm{x} / \text { hari }\end{array}$ \\
\hline $\begin{array}{l}\text { Senin } 31 \text { januari } \\
2022 \\
11.00\end{array}$ & $\begin{array}{l}\text { 1. Data } \\
\text { Tanda DAN gejala: } \\
\text { - marah marah } \\
\text { - merasa tidak dihargai } \\
\text { - Pandangan tajam } \\
\text { - Tangan mengepal } \\
\text { - Berkata kotor } \\
\text { 2. Diagnosa keperawatan } \\
\text { Resiko Perilaku } \\
\text { Kekerasan } \\
\text { 3. Tindakan keperawatan } \\
\text { Sp } 3 \\
\text { Komunikasi secara verbal: } \\
\text { Asertif/bicara baik baik } \\
\text { 4.RTL } \\
\text { Sp } 4 \\
\text { Spiritual }\end{array}$ & $\begin{array}{l}\text { S: klien merasa senang } \\
\text { O: } \\
\text { - Klien mampu melakukan } \\
\text { komunikasi secara verbal: } \\
\text { asertif/bicara baik baik dengan } \\
\text { motivasi } \\
\text { A: Resiko Perilaku Kekerasan (+) } \\
\text { P: } \\
\text { - Latihan tarik nafas dalam } 3 x \text { / } \\
\text { hari } \\
\text { - Latihan pukul kasur bantal } \\
\text { dalam } 3 x \text { / hari } \\
\text { - Latihan minum obat dengan } \\
\text { prinsip } 6 \text { benar } 2 \times \text { / hari } \\
\text { Latihan berbicara kepada } \\
\text { orang lain }\end{array}$ \\
\hline $\begin{array}{l}\text { Rabu, } 2 \text { februari } \\
2022 \\
10.00\end{array}$ & $\begin{array}{l}\text { 1. Data } \\
\text { Tanda dan Gejala } \\
\quad \text { - mengamuk } \\
\text { - memukul orang sekitar }\end{array}$ & $\begin{array}{l}\text { S: klien merasa senang melakukan } \\
\text { terapi yang diberikan }\end{array}$ \\
\hline
\end{tabular}




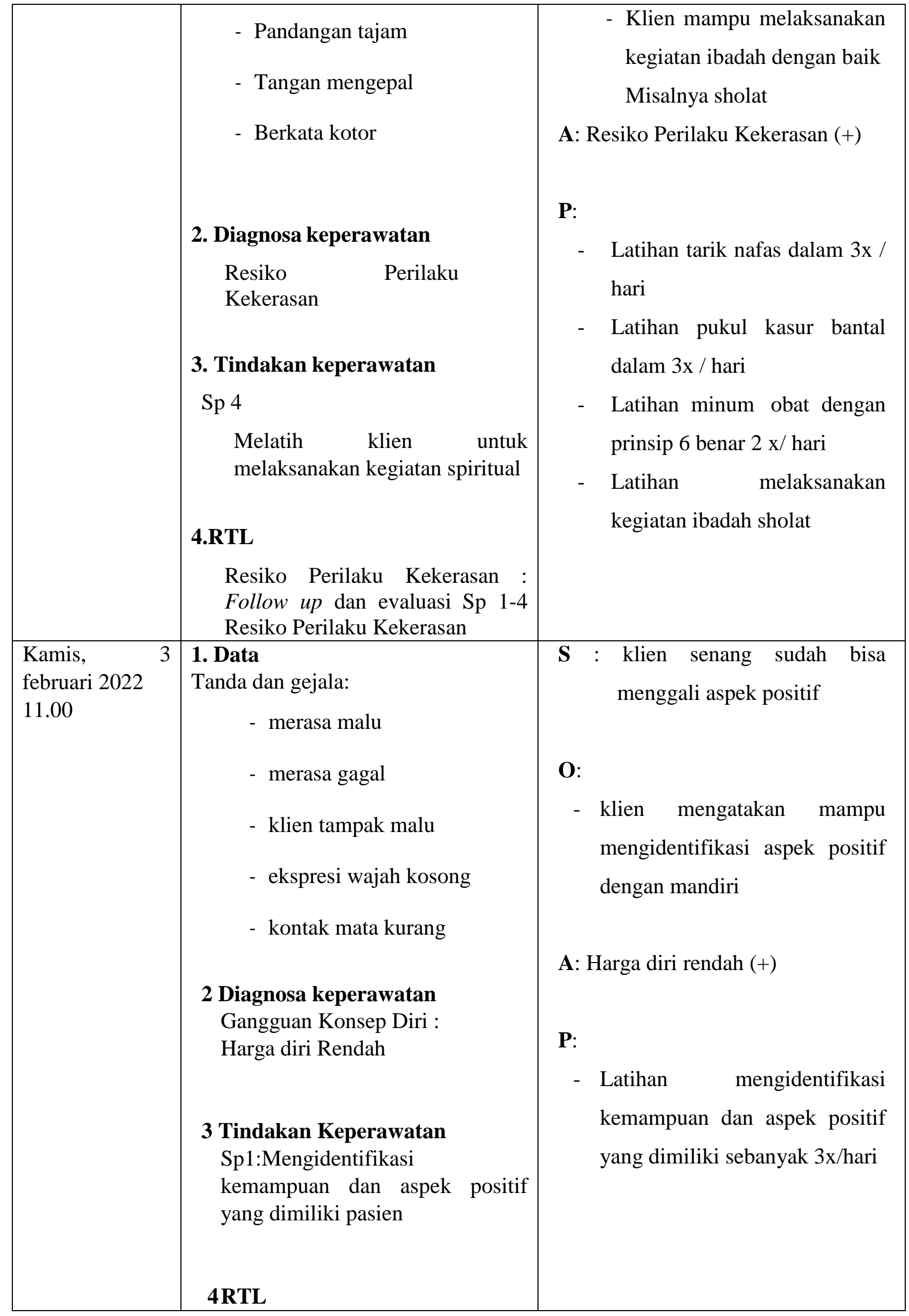




\begin{tabular}{|c|c|c|}
\hline & $\begin{array}{l}\text { SP 2: } \\
\text { - Menilai kemampuan yang } \\
\text { dapat digunakan } \\
\text { - } \text { Menetapkan / memilih kegiatan } \\
\text { sesuai kemampuan } \\
\text { - } \text { Melatih kegiatan sesuai } \\
\quad \text { kemampuan yang dipilih } 1 \\
\text { SP 3: } \\
\text { Melatih kegiatan sesuai kemampuan } \\
\text { yang dipilih } 2 \\
\text { SP 4: } \\
\text { Melatih kegiatan sesuai kemampuan } \\
\text { yang dipilih } 3\end{array}$ & \\
\hline $\begin{array}{ll}\text { Jumat, } & 4 \\
\text { februari } 2022 \\
10.00\end{array}$ & $\begin{array}{l}\text { 1. Data } \\
\text { Tanda dan Gejala: } \\
\text { - Berbicara pelan } \\
\text { - merasa putus asa karena } \\
\text { tidak bisa memberi nafkah } \\
\text { - tampak malu } \\
\text { - kontak mata kurang } \\
\text { 2 Diagnosa keperawatan } \\
\text { Gangguan Konsep Diri : } \\
\text { Harga diri Rendah } \\
\text { 3 Tindakan Keperawatan } \\
\text { SP 2: } \\
\text { - Menilai kemampuan yang } \\
\text { dapat digunakan } \\
\text { - Menetapkan / memilih kegiatan } \\
\text { sesuai kemampuan } \\
\text { - Melatih kegiatan sesuai } \\
\text { kemampuan yang dipilih } 1 \\
\text { 4 RTL } \\
\text { SP 3: } \\
\text { Melatih kegiatan sesuai kemampuan } \\
\text { yang dipilih 2 } \\
\text { Melatih }\end{array}$ & 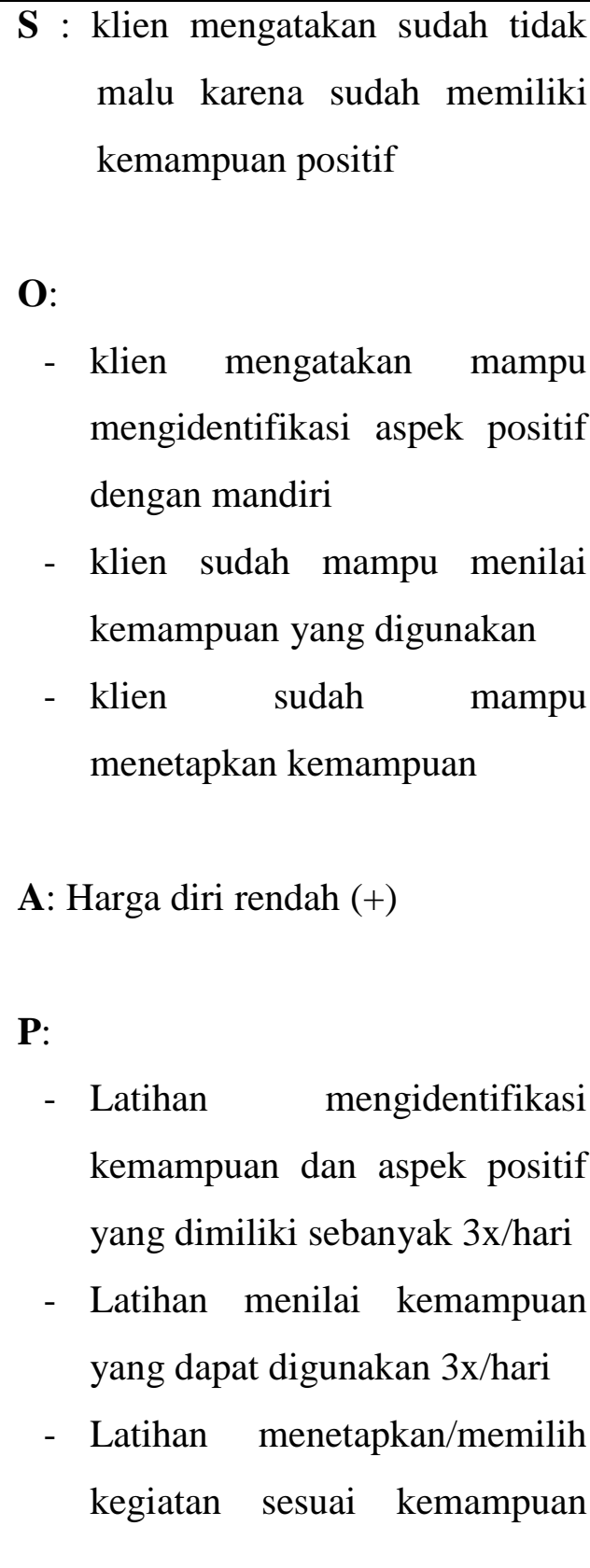 \\
\hline
\end{tabular}




\begin{tabular}{|c|c|c|}
\hline & kemampuan yang dipilih 3 & $\begin{array}{l}\text { 3x/hari } \\
\text { - Melatih kemampuan yang } \\
\text { dipilih } 13 x / \text { hari }\end{array}$ \\
\hline $\begin{array}{l}\text { Sabtu, } \quad 5 \\
\text { Februari } 2022 \\
11.00\end{array}$ & $\begin{array}{l}\text { 1. Data } \\
\text { Tanda dan gejala: } \\
\text { - Kontak mata kurang } \\
\text { - Klien merasa putus asa } \\
\text { karena tidak memberi } \\
\text { nafkah } \\
\text { - klien tampak malu } \\
\text { 2 Diagnosa keperawatan } \\
\text { Gangguan Konsep Diri : } \\
\text { Harga diri Rendah } \\
\text { 3. Tindakan Keperawatan } \\
\text { SP 3: } \\
\text { Melatih kegiatan sesuai kemampuan } \\
\text { yang dipilih } 2 \\
\text { 4 RTL } \\
\text { SP 4: } \\
\text { Melatih } \\
\text { kemampuan yang dipilih } 3\end{array}$ & 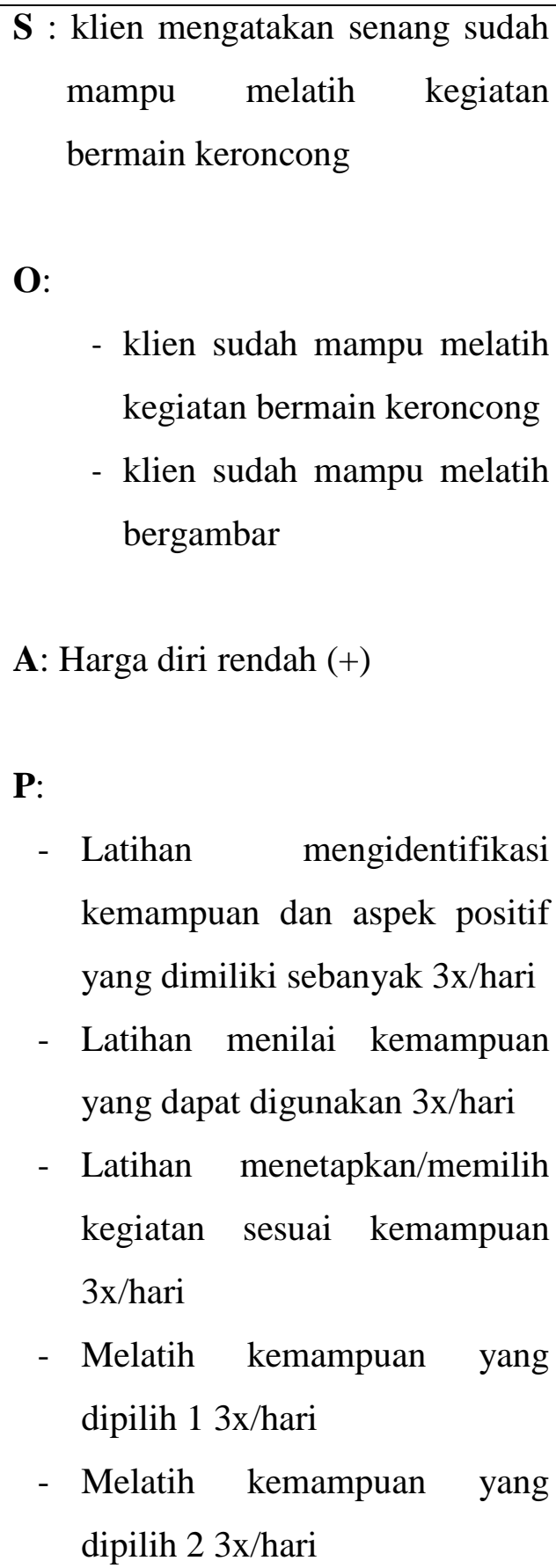 \\
\hline $\begin{array}{l}\text { Senin, } \\
\text { februari } 2022 \\
15.00\end{array}$ & $\begin{array}{l}\text { 1. Data } \\
\text { Tanda dan Gejala: } \\
\text { - Kontak mata sudah baik, } \\
\text { - } \text { Klien sudah tidak merasa } \\
\text { malu karena sudah } \\
\text { memiliki kemampuan }\end{array}$ & 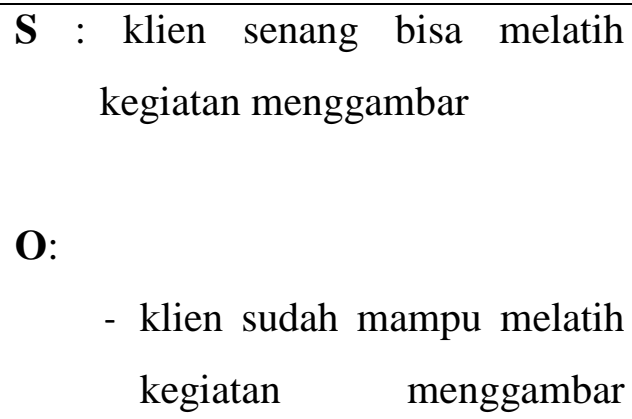 \\
\hline
\end{tabular}




\begin{tabular}{|c|c|}
\hline $\begin{array}{l}\text { - Merasa malu karena masuk } \\
\quad \text { rumah sakit jiwa } \\
\text { 2 Diagnosa keperawatan } \\
\text { Gangguan Konsep Diri : } \\
\text { Harga diri Rendah } \\
\text { 3. Tindakan Keperawatan } \\
\text { SP 4: } \\
\text { Melatih kegiatan sesuai kemampuan } \\
\text { yang dipilih } 3 \\
\text { 4 RTL } \\
\text { Harga diri Rendah : Follow up dan } \\
\text { evaluasi Sp 1-4 Harga diri Rendah }\end{array}$ & $\begin{array}{l}\text { dengan mandiri } \\
\text { - klien sudah mampu melatih } \\
\text { bergambar } \\
\text { A: Harga diri rendah (+) } \\
\text { P: } \\
\text { - Latihan mengidentifikasi } \\
\text { kemampuan dan aspek positif } \\
\text { yang dimiliki sebanyak 3x/hari } \\
\text { - Latihan menilai kemampuan } \\
\text { yang dapat digunakan 3x/hari } \\
\text { - Latihan menetapkan/memilih } \\
\text { kegiatan sesuai kemampuan } \\
\text { 3x/hari knang } \\
\text { - Melatih kemampuan yang } \\
\text { dipilih } 13 x / \text { hari } \\
\text { - Melatih kemampuan yang } \\
\text { dipilih } 23 x / h a r i \\
\text { - Melatih kemampuan yang } \\
\text { dipilih } 33 x / \text { hari }\end{array}$ \\
\hline
\end{tabular}




\section{BAB 4 \\ PEMBAHASAN}

Setelah penulis melaksanakan asuhan keperawat kepada Tn.D dengan gangguan sensori persepsi: halusinasi pendengaran Di RSJ prof. Dr. Muhammad Ildrem, maka penulis pada $\mathrm{BAB}$ ini akan membahasan kesenjangan antara teoritis dengan tinjauan kasus. Pembahasan dimulai melalui tahapan proses keperawatan yaitu pengkajian, diagnosa keparawatan, perencanaan, pelaksanaan dan evaluasi.

\subsection{Pengkajian}

Pada pembahasan ini diuraikan tentang hasil pelaksanaan tindakan keperawatan dengan pemberian terapi generalis pada klien halusinasi pendengaran. Pembahasan menyangkut analisis hasil penerapan terapi generalis terhadap masalah keperawatan halusinasi pendengaran. Tindakan keperawatan didasarkan pada pengkajian dan diagnosis keperawatan yang terdiri dari tindakan generalis yang dijabarkan sebagai berikut.

Tahap pengkajian pada klien halusinasi dilakukan interaksi perawat-klien melalui komunikasi terapeutik untuk mengumpulkan data dan informasi tentang status kesehatan klien. Pada tahap ini terjadi proses interaksi manusia, komunikasi, transaksi dengan peran yang ada pada perawat sebagaimana konsep tentang manusia yang bisa dipengaruhi dengan adanya proses interpersonal.

Selama pengkajian dilakukan pengumpulan data dari beberapa sumber, yaitu dari pasien dan tenaga kesehatan di ruangan. Penulis mendapat sedikit kesulitan dalam menyimpulkan data karena keluarga pasien jarang mengunjungi pasien di rumah sakit jiwa. Maka penulis melakukan pendekatan kepada pasien melalui komunikasi terapeutik yang lebih terbuka membantu pasien untuk memecahkan perasaannya dan juga melakukan observasi kepada pasien.

Adapun upaya tersebut yaitu:

a. Melakukan pendekatan dan membina hubungan saling percaya diri pada klien agar klien lebih terbuka dan lebih percaya dengan 
menggunakan sssperasaan.

b. Mengadakan pengkajian klien dengan wawancara

c. Mengadakan pengkajian dengan cara membaca status, melihat buku rawatan dan bertanya kepada pegawai ruangan Pusuk Buhit.

Dalam pengkajian ini, penulis menemukan kesenjangan karena ditemukan. Pada kasus Tn.D, marah-marah dan merusak barang-barang, mendengar suara suara bisikan dari keluarga mantan istrinya, klien mengganggu warga sekitar, klien pernah dirawat 1 tahun yang lalu tapi tidak rutin control dan minum obat, klien pernah menikah 2 kali tetapi bercerai karena tidak memberi nafkah.. Gejala gejala yang muncul tersebut tidak semua mencakup dengan yang ada di teori klinis dari halusnasi (Keliat,.2014). Akan tetapi terdapat faktor predisposisi maupun presipitasi yang menyebabkan kekambuhan penyakit yang dialami oleh Tn.D.

Tindakan keperawatan terapi generalis yang dilakukan pada Tn.D adalah strategi pertemuan pertama sampai pertemuan enam. Strategi pertemuan pertama meliputi mengidentifikasi isi, frekuensi, jenis, dan respon klien terhadap halusinasi serta melatih cara menghardik halusinasi dan mengontrol halusinasi dengan minum obat. Strategi pertemuan kedua yang dilakukan pada Tn.D meliputi melatih cara mengendalikan dengan bercakap-cakap kepada orang lain dan menyusun jadwal kegiatan bersama-sama dengan klien. Strategi pertemuan keempat adalah mengajarkan klien tarik nafas dlam, pukul kasur bantal dan minum obat secara teratur. Strategi ke lima adalah mengajarkan klien berbicara baik baik dan berdoa. Strategi ke lima adalah mengajarkan klian menidentifikasi kemampua, aspek positif yang dimiliki. Strategi enam adalah mengajarkan klien kegiatan sesuai kemampuan yang dipilih 2 dan dipilih 3 .

\subsection{Diagnosa Keperawatan}

Pada Teori Halusinasi (NANDA, 2015-2017), diagnosa keperawatan yang muncul sebanyak 3 diagnosa keperawatan (Aji, 2019) yang meliputi:

1. Resiko Perilaku Kekerasan

2. Halusinasi Pendengaran

3. Harga diri rendah 
Sedangkan pada kasus Tn.D ditemukan tiga diagnosa keperawatan yang muncul yang meliputi: halusinasi, resiko perilaku kekerasan, harga diri rendah. Dari hal tersebut di atas dapat dilihat terjadi kesamaan antara teori dan kasus. Dimana semua diagnosa pada teori muncul pada kasus Tn.D

\subsection{Intervensi Keperawatan}

Perencanaan dalam proses keperawatan lebih dikenal dengan rencana asuhan keperawatan yang merupakan tahap selanjutnya setelah pengkajian dan penentuan diagnose keperawatan. Pada tahap perencanaan penulis hanya menyusun rencana tindakan keperawatan sesuai dengan pohon masalah keperawatan yaitu : Gangguan persepsi sensori : Halusinasi pendengaran (Kelliat,2016)

Pada tahap ini antara tinjauan teoritis dan tinjauan kasus tidak ada kesenjangan sehingga penulis dapat melaksakan tindakan seoptimal mungkin dan didukung dengan tersedianya sarana rungan perawat yang baik dan adanya bimbingan dan petunjuk dari petugas kesehatan dari rumah sakit jiwa yang diberkan kepada penulis. Secara teoritis digunakan cara strategi pertemuan sesuai dengan diagnose keperawtan yang muncul saat pengkajian. Adapun upaya yang dilakukan penulis yaitu:

1. Gangguan persepsi sensori : Halusinasi

a. Identifikasi isi, waktu terjadi, situasi pencetus, dan respon terhadap halusinasi

b. Mengontrol halusinasidengan cara menghardik

c. Mengontrol Halusinasi dengan cara minum obat secara teratur

d. mengontrol halusinasi dengancara bercakap - cakap dengan orang lain

e. mengontrol halusinasi dengan cara melakukan aktifitas terjadwal 
2. Resiko perilaku kekerasan

a. Mengontrol perilaku kekerasan dengan cara: Latihan fisik 1 : tarik nafas dalam, Latihan fisik 2 : pukul kasur bantal

b. Mengontrol perilaku kekerasan dengan cara minum obat secara teratur

c. Komunikasi secara verbal: Asertif/bicara baik baik

d. Spiritual

3. Harga diri rendah

a. Mengidentifikasi kemampuan dan aspek positif yang dimiliki pasien

b. Menilai kemampuan yang dapat digunakan

c. Menetapkan / memilih kegiatan sesuai kemampuan

d. Melatih kegiatan sesuai kemampuan yang dipilih 1

e. Melatih kegiatan sesuai kemampuan yang dipilih 2

f. Melatih kegiatan sesuai kemampuan yang dipilih 3

\subsection{Implementasi Keperawatan}

Implementasi, adalah tahap dimana perawat memulai melakukan tindakan penulis hanya mengatasi masalah keperawatan halusinasi pendengaran. Dengan melakukan strategi pertemuan yaitu mengidentifikasi isi, frekuensi, waktu terjadi, perasaan, respon halusinasi. Kemudian strategi pertemuan yang dilakukan yaitu latihan mengontrol halusinasi dengan cara menghardik. Strategi pertemuan yang kedua yaitu anjurkan minum obat secara teratur, strategi pertemuan yang ke tiga yaitu latihan dengan cara bercakap - cakap pada saat aktivitas dan latihan strategi pertemuan ke empatyaitu melatih klien melakukankegiatan terjadwal.

\subsection{Evaluasi}

Pada tinajauan teoritis evaluasi yang diharapkan adalah: Pasien mempercayai perawat sebagai terapis, pasien menyadari bahwa yang dialaminya tidak ada objeknya, dapat mengidentifikaasi halusinasi, dapat mengendalikan halusinasi melalui mengahrdik, latihan bercakap-cakap, 
melakukan aktivitas serta menggunakan obat secara teratur.

Pada tinjauan kasus evaluasi yang didapatkan adalah: Klien mampu mengontrol dan mengidentifikasi halusinasi, Klien mampu melakukan latihan bercakap-cakap dengan orang lain, Klien mampu melaksanakan jadwal yang telah dibuat bersama, Klien mampu memahami penggunaan obat yang benar: 5 benar. Selain itu, dapat dilihat dari setiap evalusi yang dilakukan pada asuhan keperawatan, dimana terjadi penurunan gejala yang dialami oleh Tn.D dari hari kehari selama proses interaksi. 


\section{BAB 5 \\ PENUTUP}

\subsection{Kesimpulan}

Setelah menguraikan tentang proses keperawatan pada Tn.D dan disimpulkan bahwa klien dapat berorientasi secara realita dan mengatasi halusinasi pendengaran dengan terapi yang diajarkan mahasiswa. Maka dapat diambil keputusan sebagai berikut pengkajian yang dilaksanakan tidak banyak berbeda dengan pengkajian teoritismaupun penulis tidak mendapat kesulitan dalampengkajian klien.Berdasarkan uraian pada pembahasan di atas, maka penulis dapat disimpulkan bahwa:

1. Pengkajian dilakukan secara langsung pada klien dan juga dengan menjadikan status klien sebagai sumber informasi yang dapat mendukung data-data pengkajian. Selama proses pengkajian, perawat mengunakan komunikasi terapeutik serta membina hubungan saling percaya antara perawat-klien. Pada kasus Tn.D, diperoleh bahwa klien mengalami gejala-gejala halusinasi seperti , marah-marah dan merusak barang-barang, mendengar suara suara bisikan dari keluarga mantan istrinya, klien mengganggu warga sekitar, klien pernah dirawat 1 tahun yang lalu tapi tidak rutin control dan minum obat, klien pernah menikah 2 kali tetapi bercerai karena tidak memberi nafkah. Faktor predisposisi pada Tn.D yaitu pernah mengalami gangguan jiwa sebelumnya serta memiliki riwayat mengonsumsi ganja.

2. Diagnosa keperawatan yang muncul pada kasus Tn.D,:Halusinasi pendengaran, Resiko perilaku kekerasan, harga diri rendah. Tetapi pada pelaksanaannya, penulis fokus pada masalah utama yaitu halusinasi pendengaran.

3. Perencanaan dan implementasi keperawatan disesuaikan dengan strategi pertemuan pada pasien halusinasi pendengaran dan harga diri.

4. Evaluasi diperoleh bahwa terjadi peningkatan kemampuan klien 
dalam mengendalikan halusinasi yang dialami serta dampak pada penurunan gejala halusinasi pendengaran yang dialami.

\subsection{Saran}

1. Bagi Perawat

Diharapkan dapat menerapkan komunikasi terapeutik dalam pelaksanaan strategi pertemuan 1- 4 pada klien dengan halusinasi sehingga dapat mempercepat proses pemulihan klien.

\section{Bagi Pasien}

Diharapkan pasien dapat menetapkan terapi yang telah diberikan baik secara medik maupun terapi keperawatan yang telah diajarkan demi percepatan penyembuhan penyakit dengan masalah gangguan jiwa 


\section{DAFTAR PUSTAKA}

1. Avidha, M., \& Fitriani, D. R. (2018). Analisis Praktik Klinik Keperawatan Jiwa pada Klien Gangguan Sensori Persepsi: Halusinasi dengan Intervensi Inovasi Terapi Penerimaan dan Komitmen (Acceptance And Comitment Therapy) Terhadap Tanda dan Gejala Halusinasi di Ruang Punai RSUD Atma Husada Mahakam Samarinda https://dspace.umkt.ac.id//handle/463.2017/201

2. Ellina, A. (2012). Pengaruh Terapi Aktifitas Kelompok (Tak) Stimulasi Persepsi Sessi 1-3 Terhadap Kemampuan Mengendalikan Halusinasi Pada Pasien Skizofrenia Hebefrenik. STRADA Jurnal Ilmiah Kesehatan, 1(1), 56-62. Retrieved from https://sjik.org/index.php/sjik/article/view/22

3. PPNI, T. P. S. D. (2018). Standar intervensi keperawatan indonesia.

4. Fadli, S. M., \& Mitra, M. (2013). Pengetahuan dan ekspresi emosi keluarga serta frekuensi kekambuhan penderita skizofrenia. Kesmas: Jurnal Kesehatan Masyarakat Nasional (National Public Health Journal), 7(10), 466-470 http://dx.doi.org/10.21109/kesmas.v7i10.6

5. Fitri, N. Y. (2019). Pengaruh Terapi Okupasi terhadap Gejala Halusinasi Pendengaran Pada Pasien Halusinasi Pendengaran Rawat Inap di Yayasan Aulia Rahma Kemiling Bandar Lampung. Jurnal Kesehatan Panca Bhakti Lampung, 7(1), 3340 https://doi.org/10.47218/jkpbl.v7i1.58

6. Hafizuddin, D. T. M. (2021). Asuhan Keperawatan Jiwa Pada Tn. A Dengan Masalah Halusinasi Pendengaran https://doi.org/10.31219/osf.io/9xn25

7. Pardede, J. A., Keliat, B. A., \& Yulia, I. (2015). Kepatuhan dan Komitmen Klien Skizofrenia Meningkat Setelah Diberikan Acceptance And Commitment Therapy dan Pendidikan Kesehatan Kepatuhan Minum Obat. Jurnal Keperawatan Indonesia, 18(3), 157166.

8. Pardede, J.A, Irwan, F., Hulu, E. P., Manalu, L. W., Sitanggang, R., \& Waruwu, J. F. A. P. (2021). Asuhan keperawatan Jiwa Dengan Masalah Halusinasi. https://doi.org/10.31219/osf.io/fdqzn

9. Wijayati, F., \& Nurfantri, N. (2019). Penerapan Intervensi Manajemen Halusinasi terhadap Tingkat Agitasi pada Pasien Skizofrenia. Health Information: Jurnal Penelitian, 11(1), 1319. https://doi.org/10.36990/hijp.v11i1.86

10. Sianturi, S. F. (2021). Aplikasi Asuhan Keperawatan Jiwa Pada Ny. H Dengan Masalah Halusinasi. 
11. Patricia, H., Rahayuningrum, D. C., \& Nofia, V. R. (2019). Hubungan beban keluarga dengan kemampuan caregiver dalam merawat klien skizofrenia. Jurnal Kesehatan Medika Saintika, 10(2), 45-52.

12. Riskesdas, L. N. (2018). Kementerian Kesehatan RI Badan Penelitian dan Pengembangan Kesehatan.

13. Pardede, J. A. (2022). Koping Keluarga Tidak Efektif Dengan Pendekatan Terapi Spesialis Keperawatan Jiwa.

14. Pardede, J. A. (2019). The Effects Acceptance and Aommitment Therapy and Health Education Adherence to Symptoms, Ability to Accept and Commit to Treatment and Compliance in Hallucinations Clients Mental Hospital of Medan, North Sumatra. J Psychol Psychiatry Stud, 1, 30-35.

15. Yuanita, T. (2019). Asuhan Keperawatan Klienskizofrenia Dengan Gangguan Persepsi Halusinasi Pendengaran Di Rsjd Dr. Arif Zainudin Solo Surakarta (Doctoral dissertation, Universitas Muhammadiyah Ponorogo) http://eprints.umpo.ac.id/id/eprint/5381

16. Sulahyuningsih, E., Pratiwi, A., \& Teguh, S. (2016). Pengalaman Perawat Dalam Mengimplementasikan Strategi Pelaksanaan (Sp) Tindakan Keperawatan Pada Pasien Halusinasi Di Rumah Sakit Jiwa Daerah Surakarta (Doctoral dissertation, Universitas Muhammadiyah Surakarta).

17. Pardede, J. A. (2020). Family Burden Related to Coping when Treating Hallucination Patients. Jurnal Ilmu Keperawatan Jiwa, 3(4), 453-460.

18. Pardede, J. A. (2020). Decreasing Hallucination Response Through Perception Stimulation Group Activity Therapy In Schizophrenia Patients. Iar Journal of Medical Sciences, 1(6), 304-309.

19. Ngapiyem, R., \& Kurniawan, E. A. P. B. (2019). Hubungan antara Dukungan Keluarga Dengan Kemampuan Klien Mengontrol Halusinasi Pedengaran Di Soedarjo Provinsi Jawa Tengah Tahun 2018. https://doi.org/10.35913/jk.v6i2.121.

20. Maharani, Y., \& Noviekayati, I. G. A. A. (2019, November). Permainan Catur Sebagai Media Perubahan Perilaku untuk Penderita Skizofrenia Hebefrenik. In Prosiding Seminar Nasional Multidisiplin

21. Pardede, J. A., Damanik, R. K., Simanullang, R. H., \& Sitanggang, R. (2020) The Effect Of Cognitive Therapy On Changes In Self-Esteem On Schizophrenia Patients. European Journal of Molecular \& Clinical Medicine, 7(11), 2020.

22. Pardede, J. A. (2020). Family Burden Related to Coping when Treating Hallucination Patients. Jurnal Ilmu Keperawatan Jiwa, 3(4), 453-460. https://doi.org/10.32584/jikj.v3i4.671 
23. Kusumawati, F. Hartono, \& Yudi.(2012). Buku Ajar Keperawatan Jiwa. Jakarta: Salemba Medika.

24. Pardede, J. A. (2021). Standar Asuhan Keperawatan Dengan Kesiapan Peningkatan Pengetahuan.

25. Manao, B. M., \& Pardede, J. A. (2019). Correlation of Family Burden of The Prevention of Recurrence of Schizophrenia Patients. Mental Health, 4(1), 31-42.

26. Santri, T. W. (2021). Asuhan Keperawatan Jiwa Dengan Masalah Gangguan Persepsi Sensori: Halusinasi Pendengaran Pada Ny. S.

27. Pardede, J. A. (2020). Family Knowledge about Hallucination Related to Drinking Medication Adherence on Schizophrenia Patient. Jurnal Penelitian Perawat Profesional, 2(4), 399-408.

28. Pardede, J. A., Silitonga, E., \& Laia, G. E. H. (2020). The Effects of Cognitive Therapy on Changes in Symptoms of Hallucinations in Schizophrenic Patients. Indian Journal of Public Health, 11(10), 257.

29. Atmojo, B. S. R., \& Purbaningrum, M. A. (2021). Literature Review: Penerapan Latihan Kemampuan Positif Terhadap Peningkatan Harga Diri Rendah Pada Klien Yang Mengalami Skizofrenia Dengan Gangguan Konsep Diri Harga Diri Rendah. Nursing Science Journal (NSJ), 2(1), 55-62.

30. Dwi, S. C. (2020). Asuhan Keperawatan Pada Klien Skizofrenia Dengan Masalah Harga Diri Rendah Kronik (Doctoral Dissertation, Universitas Muhammadiyah Ponorogo). 